\title{
Hooliganism in the Shadow of the 9/11 Terrorist Attack and the Tsunami: Do Police Reduce Group Violence?
}

\author{
Panu Poutvaara \\ University of Helsinki and HECER \\ and \\ Mikael Priks \\ University of Munich
}

Discussion Paper No. 134

November 2006

ISSN 1795-0562

HECER - Helsinki Center of Economic Research, P.O. Box 17 (Arkadiankatu 7), FI-00014 University of Helsinki, FINLAND, Tel +358-9-191-28780, Fax +358-9-191-28781, E-mail info-hecer@helsinki.fi, Internet www.hecer.fi 


\title{
Hooliganism in the Shadow of the 9/11 Terrorist Attack and the Tsunami: Do Police Reduce Group Violence?*
}

\begin{abstract}
This paper isolates the causal effect of policing on group violence, using unique panel data on self-reported crime by soccer and ice hockey hooligans. The problem of reverse causality from violence to policing is solved by two drastic reallocations of the Stockholm Supporter Police unit to other activities following the 9/11 terrorist attack in September 2001 and the Tsunami catastrophe in December 2004. Difference-in-difference analysis reveals that Stockholm-related hooligan violence increased dramatically during these periods.
\end{abstract}

JEL Classification: K10, K42.

Keywords: Police, Violence, Hooliganism, Natural Experiments.

Panu Poutvaara

Department of Economics

University of Helsinki

P.O. Box 17 (Arkadiankatu 7)

FI-00014 University of Helsinki

FINLAND

e-mail: panu.poutvaara@helsinki.fi
Mikael Priks

Center for Economic Studies

University of Munich

Schackstrasse 4

80539 Munich

GERMANY

e-mail: mikael.priks@lmu.de

* We are grateful for comments from Alberto Alesina, Matz Dahlberg, Stefano Della Vigna, Henrik Jordahl, Ethan Kaplan, Katarina Keller, Hans Löfdahl, Torsten Persson, Per Pettersson-Lidbom, Andrei Shleifer, David Strömberg, Daniel Sturm, Jakob Svensson, Jenny Säve-Söderbergh, and seminar participants at the University of Helsinki, IIES at Stockholm University, the University of Utrecht, and conference participants at the 2006 CESifo Public Sector Area Conference (Munich, Germany), the Scandinavian Research Council for Criminology research seminar (Reykholt, Iceland), and the 2006 IIPF congress (Paphos, Cyprus). 


\section{Introduction}

A fundamental problem in the law and economics literature is to empirically evaluate the effect of policing on crime. The challenge arises as policing is likely to respond to changes in crime, causing a problem of reverse causality. In a seminal contribution, Levitt (1997) uses the timing of gubernatorial and mayoral elections to instrument for police presence. A problem with the analysis is that the timing of the elections may affect crime in other ways than through police officers on the street, for example by affecting the sentencing behavior of judges. Moreover, McCrary (2002) shows that after adjusting for a computational error (see also Levitt's reply, 2002) the results are not statistically significant. ${ }^{1}$

Using natural experiments, Di Tella and Schargrodsky (2004) and Klick and Tabarrok (2005) exploit exogenous variation in police presence that was caused by terrorist attacks or the threat thereof. Di Tella and Schargrodsky (2004) take advantage of the increase in policing that arose due to a terrorist attack on the main Jewish center in Buenos Aires in 1994. They find that auto theft declined by seventy five percent on blocks that were protected due to the terrorist attack, compared to other blocks. Klick and Tabarrok (2005) study changes in the terror alert level set by the U.S. Department of Homeland Security as it creates an exogenous shock to the police presence in Washington, D.C. They conclude that the level of crime, in particular auto-related crime, was significantly reduced when the threat level was elevated.

An important potential problem when using changes in policing due to changes in terror-threat levels is that criminals may fear for their own safety, and be reluctant to operate in areas in which there is an increased perceived risk of being harmed or dying in a terrorist attack. This could especially be the case with auto theft as criminals may perceive that some cars in sensitive areas could be left by terrorists and be trapped with bombs. ${ }^{2}$ If this is the case, then the previous contributions may effectively find

\footnotetext{
${ }^{1}$ The endogeneity problem of policing and crime has also been addressed by Marvell and Moody (1996) using Granger causality and Corman and Mocan (2000) using high-frequency data.

${ }^{2}$ In Buenos Aires, this fear could have been triggered by the fact that car bombs were used in the attack in 1994 and in one earlier attack in 1992.
} 
the joint effect of increased policing and increased terrorist threat, signaled by elevated police presence. ${ }^{3}$ Ideally, one would like to use exogenous changes in policing that have no connection to local safety threats.

We analyze the causal impact of policing on violent crime by hooligans using two natural experiments, in which variation in policing arises for reasons stemming from outside the country. The 9/11 terrorist attack and the Asian Tsunami in December 2004 had drastic effects on a particular Swedish police unit. The Stockholm police has had a special supporter police unit, consisting of up to six police officers, monitoring potentially violent supporters of three Stockholm clubs since 1992. After the 9/11 terrorist attack until the end of the 2001 soccer season, the supporter police unit was reallocated and occupied with anti-terrorism rather than monitoring supporter club activities. After the Tsunami catastrophe in December 2004 until the beginning of April 2005, the police unit was responsible for incoming goods from Swedish victims.

To study the effects of these events on hooligan violence, we use unique data on selfreported violent crime collected by the supporter club "Firman Boys", which associates itself with the Stockholm club AIK, and is one of the main Swedish hooligan groups. Their data reports all major acts of violence with Swedish supporter clubs involved in the period the supporter police unit has existed. Many Swedish clubs have teams both in the higher soccer and ice hockey league, and violent supporters are typically involved in both sports. We are therefore able to study two related time series. Because the reallocation of the police unit only took place in Stockholm, we compute difference-indifference estimates of the effect of policing on violence.

During the time when the Stockholm Supporter Police was reallocated due to the Tsunami (January 3, 2005 to April 3, 2005) there were four reported large Stockholmrelated hooligan incidents. The average number of Stockholm-related violent incidents

\footnotetext{
${ }^{3}$ Di Tella and Schargrodsky (2004) discuss the possibility that drivers may have preferred to avoid parking close to the protected Jewish institutions due to the terror threat. They argue that this hypothesis finds no support because the decline in car theft stayed constant for about five months after the attack, i.e., until the end of their considered time period. However, whenever increased policing is a signal of a terror threat, then drivers and thieves may respond to this as long as increased police presence continues. While Klick and Tabarrok (2005) do not address the possibility that criminals could have been affected by the increased terror threat in Washington, D.C., they control for the presence of tourists, concluding that crime reduction was not driven by a reduction in tourism.
} 
during such an ice hockey period was approximately one. There were two Stockholmrelated violent incidents between October 12, 2001 and October 27, 2001 when the Stockholm Supporter Police was reallocated due to the 9/11 terrorist attack, compared to the average in such a soccer period of approximately one half. Difference-indifference analysis confirms, using various specifications, that the effects are statistically significant.

Unrest surrounding games is common in Sweden and hooligan fights often lead to physical injuries and extensive material damage. Although we use Swedish data, the phenomenon is by no means limited to Sweden. It has been, and still is, a large problem also in many other European countries, such as England, the Netherlands and Italy (Frosdick and Marsh, 2005) and in Latin American countries, like Argentina and Brazil (Archetti and Romero, 1994).

Our analysis builds on the pioneering contributions by Di Tella and Schargrodsky (2004) and Klick and Tabarrok (2005). Our approach does, however, differ from the previous literature in several important aspects. First, the terrorist attack and the Tsunami took place outside the nation's borders. This reduces the possibility that criminals are directly affected by the events, either by being afraid of potential terror attacks or by increased civility. ${ }^{4}$ Second, we use self-reported crime. This avoids measurement errors in official statistics that might be affected by changed police activities. ${ }^{5}$ According to the Head of the Stockholm Supporter Police Unit, the data reported on the hooligan web site is of high quality, and more comprehensive than police data. Third, the causal effect of policing on violence by organized groups has not been analyzed in previous literature. A benefit of this analysis is that because information spreads quickly within the group, a change of policing is likely to promptly become public knowledge. Fourth, the change we analyze amounts to a complete closing down of the unit at the center of interest, as opposed to increases in policing in

\footnotetext{
${ }^{4}$ For example, the crime rate was reduced in New York immediately after the $9 / 11$ terrorist attack due to a rise in civility (see Di Tella and Schargrodsky 2004). Many Swedes were victims of the Tsunami, but in our view it is not likely that hooligans' behavior was affected. In any event, we find no reason to believe that only Stockholm hooligans would have been affected.

${ }^{5}$ It may be that the hooligan organization which reports violence over-represents its own activity. However, this bias should be consistent over time and will therefore not distort our results.
} 
previous literature. As the periods of reallocation were short, we also believe that we, like Di Tella and Schargrodsky (2004) and Klick and Tabarrok (2005), are capturing deterrence rather than incapacitation.

The rest of the paper is organized as follows. We describe the data in Section 2. In Section 3, we present the empirical strategy and the results. Section 4 concludes.

\section{Data}

We study violence by hooligan groups, typically called "firms". Each firm is attached to a soccer and/or an ice hockey club and organizes fights with other firms, which take place on the day of the match, and from time to time on the preceding or following day. The fights are sometimes located outside the arena, but often further away since hooligans want to avoid police presence.

Several countries, including Sweden, have specialized police units to target hooliganism. This "supporter police" is an intelligence unit that monitors hooligan organizations attached to ice hockey and soccer clubs. The police aim to obtain detailed information about the individuals in the organizations, and to discourage violence by their presence. The supporter police in Stockholm keep track of potentially violent supporters attached to the three Stockholm clubs AIK, Djurgårdens IF and Hammarby IF. This means that apart from being at the home games, they often follow the teams on the away games. When a supporter police officer has information about an upcoming violent clash, he informs other police units so that they can intervene. If he observes violence, it is filmed and later analyzed in detail in order to find out which particular hooligans can be prosecuted. He may finally serve as witness in a trial. From the hooligans' perspective, the presence of the supporter police is therefore a large threat which could, and also often does, lead to imprisonment. According to the largest hooligan organization "Firman Boys" itself, the members are closely monitored by the police.

There are currently six officers in the Stockholm unit, two in the Gothenburg unit and two in the unit covering the southernmost part of Sweden, Skåne. We have been in contact with the head of the Stockholm unit, Hans Löfdahl. 
Following the 9/11 terrorist attack, the supporter police unit in Stockholm was reallocated to guard a Stockholm mosque. The precise time period was from October 8, 2001 until October 30, 2001, i.e., beyond the end of the soccer season. In addition, the supporter police in Stockholm was not working on its normal duties, but was instead responsible for incoming goods from Swedish victims of the Tsunami from January 3, 2005 until April 3, 2005. We use these exogenous sources of variation in policing to identify the effect of the supporter police on hooligan violence. Because the changes only affected the Stockholm police, we will use games when Stockholm teams were involved as the treatment group and the other games as the control group. There is reason to expect that the information of the police reallocation spreads quickly. Supporter police are visible in games and discussions with the Head of the Stockholm Supporter Police Unit reveals that the supporters he monitors are aware of their presence or absence. ${ }^{6}$ Moreover, the mosque that the supporter police was standing in front of after the terrorist attack is very close to a pub which is frequently visited by supporters of one of the Stockholm clubs. The hooligans may therefore have become aware of their reallocation very quickly.

The violence data we use is collected by Sweden's largest hooligan organization "Firman Boys". They are supporting the Stockholm club AIK, and have recorded all major violent events in connection with soccer and ice hockey games in Sweden since 1990. The data is well-structured, well-written and is, according to the supporter police, of high quality. We use data on all games from the major Swedish ice hockey leagues and from the highest level Swedish soccer league, "Allsvenskan".7 The time span we consider is from 1992 when the supporter police was formed until April $2006 .^{8}$

Supporters have in many cases been wounded and sometimes suffered from life threatening injuries due to hooligan fights. According to Firman Boys, the data set contains "major incidents in connection to soccer and ice hockey when Swedish hooli-

\footnotetext{
${ }^{6}$ In fact, after a police officer has been on a shorter vacation, it is not uncommon that some of the hooligans ask "where have you been?".

${ }^{7}$ About 75 percent of the soccer-related violent incidents reported by Firman takes place in the highest level league, Allsvenskan.

${ }^{8}$ The information is reported at www.sverigescenen.com.
} 
gans have been involved." There are occasions when the teams playing in the game are not the same as the firms fighting in which case we report the fighting firms. Like Firman Boys, we also report occasions when hooligans normally attached to ice hockey clubs fight in connection with the winter sport "bandy". ${ }^{9}$ We use two different measures of violence. The first is the number of incidents in all games during the period of consideration. We have also constructed an index from 1 to 3 , where the minimum level of reported violence is denoted by 1 . More severe violence, either in terms of injuries or in terms of the number of individuals involved is denoted by 2 . The highest level of violence is denoted by 3 . It is characterized by large scale group violence, or the involvement of weapons like knives, or kicking individuals lying on the ground, leading to severe injuries. When calculating each club's involvement in violence, each fight is counted for both clubs participating.

\subsection{Ice hockey}

There are 39 violent incidents reported from the fall season of 1992 until the end of the spring season 2006. Table I shows the number of violent incidents team-by-team and year-by-year. The three Stockholm teams have been involved in 77 percent of the violent incidents.

We collapse the data into two periods per year; the fall season and the spring season. The Tsunami disaster took place on December 26, 2004, and the reallocation of the Stockholm Supporter Police Unit took place from January 3, 2005 until April 3, 2005. Figure 1 shows the number of violent incidents within each period. There are 28 periods where period number 26 is the reallocation period. The average number of Stockholm-related incidents in other periods is 0.96 . In the reallocation period, there were four incidents. The period of reallocation is marked with an arrow.

\footnotetext{
${ }^{9}$ We group these incidents and call it "ice hockey-related violence". The participants in the fights related to the different sports are by and large the same.
} 


\section{FIGURE 1. VIOLENCE RELATED TO ICE HOCKEY}

WITH STOCKHOLM CLUBS

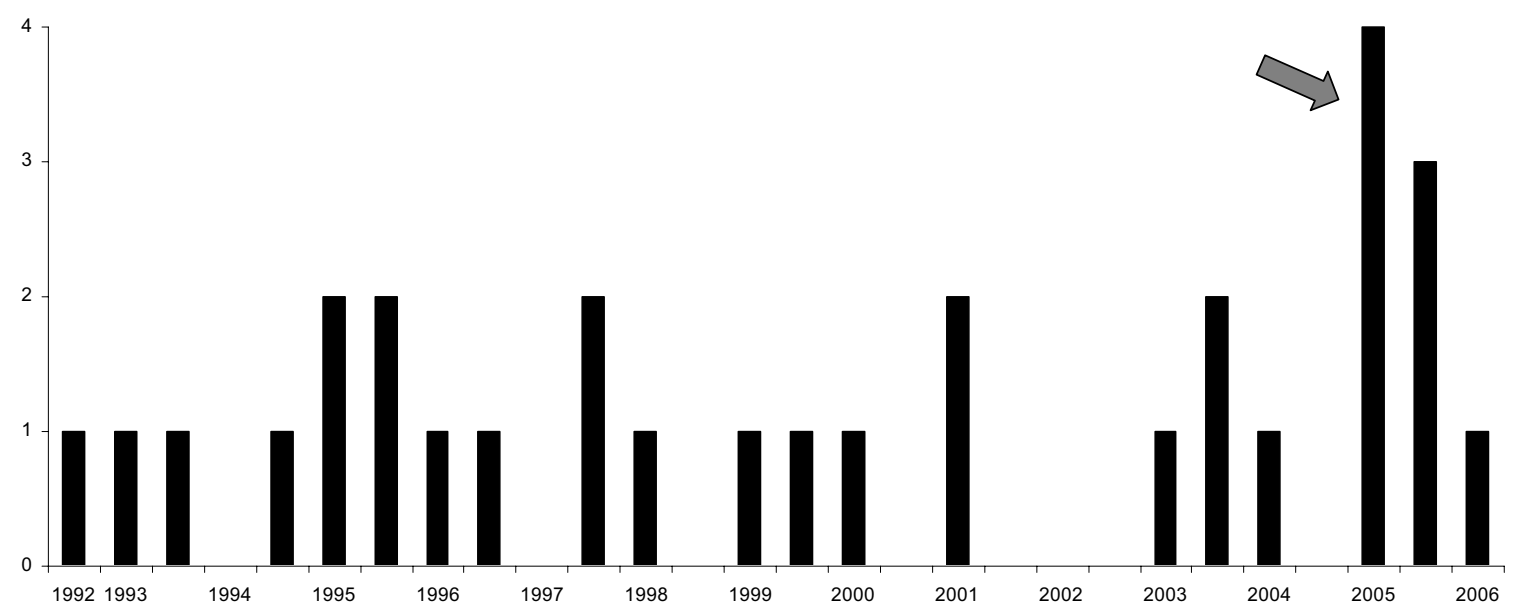

Figure 2 shows the differences between Stockholm-related violence and violence not related to the Stockholm teams. The reallocation period is noticeable because while non-Stockholm supporters sometimes fight each other, in the reallocation period they did not.

FIGURE 2. VIOLENCE RELATED TO ICE HOCKEY

WITH STOCKHOLM CLUBS MINUS WITHOUT

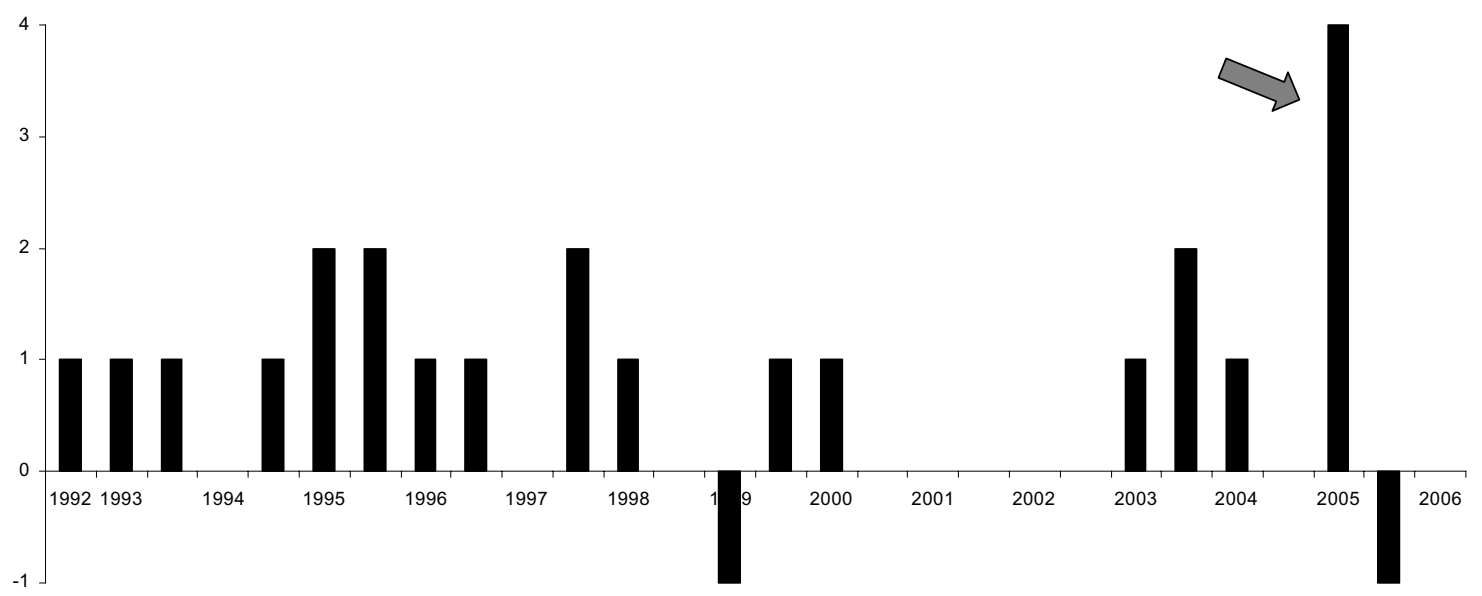

The figures using the index of violence rather than the number of violent incidents look similar. The level of Stockholm-related violence in the reallocation period is then 
8. This is more than four times as high as the average of Stockholm-related violence in other periods, which is 1.81 .

\subsection{Soccer}

There were ten teams in the highest league "Allsvenskan" in 1992 and after that fourteen teams per year. There are 130 "major violent incidents" in the highest league reported from 1992 to $2005 .^{10}$ Table II shows the number of incidents team-by-team and year-by-year. The first five columns show the five most violent supporter clubs and the sixth column sums the violence of the other clubs. Not all teams have been in the highest league throughout the period, which is marked by a line. The supporters of the three Stockholm clubs AIK, Djurgårdens IF and Hammarby IF, and IFK Göteborg from Gothenburg, are noticeable as being much more violent than supporters of other teams. Clubs supporting other teams, none of which is from Stockholm, account for much less violence per team. Together, however, they have consistently played a role on the Swedish hooligan scene. The supporters of the three Stockholm teams are involved in 78 percent of violent incidents.

The police were reallocated to guard a mosque on the 8th of October 2001. According to the supporter police, violent supporters realize quickly when the unit is not present. We assume that it took four days from the actual reallocation of the police unit until the Stockholm supporter clubs had obtained this information. ${ }^{11}$ This implies that there were 16 days left until the season ended in 2001, which was on the 27th of October. We therefore collapse the data into thirteen 16-day periods per year. We will use dummies to control for the different periods within a year. Figure 3 shows the number of violent incidents for the three Stockholm teams and for the 182 time periods. The reallocation period, when the supporter police was not monitoring the

\footnotetext{
${ }^{10}$ The soccer season 2006 was not over at the time this paper was written.

${ }^{11}$ For example, the police once asked door men in different bars in Stockholm to help finding information about hooligans. After four days, a supporter club announced on its home page that this action was taken by the police. The police officer we have been in contact with suggested that some hooligans may well have seen him or his colleagues in their new duties they took on from October 8 , 2001. Moreover, since hooliganism is a group phenomenon, and because fights are coordinated, it is sufficient that one hooligan gets the information for it to become public.
} 
hooligans took place from October 12, 2001 until October 27, 2001. The number of violent incidents in the reallocation period was two, compared to the average in other periods of 0.55 . The total level of violence according to our index was four, almost four times the average of 1.02 .

FIGURE 3. VIOLENCE RELATED TO

"ALLSVENSKAN" WITH STOCKHOLM CLUBS

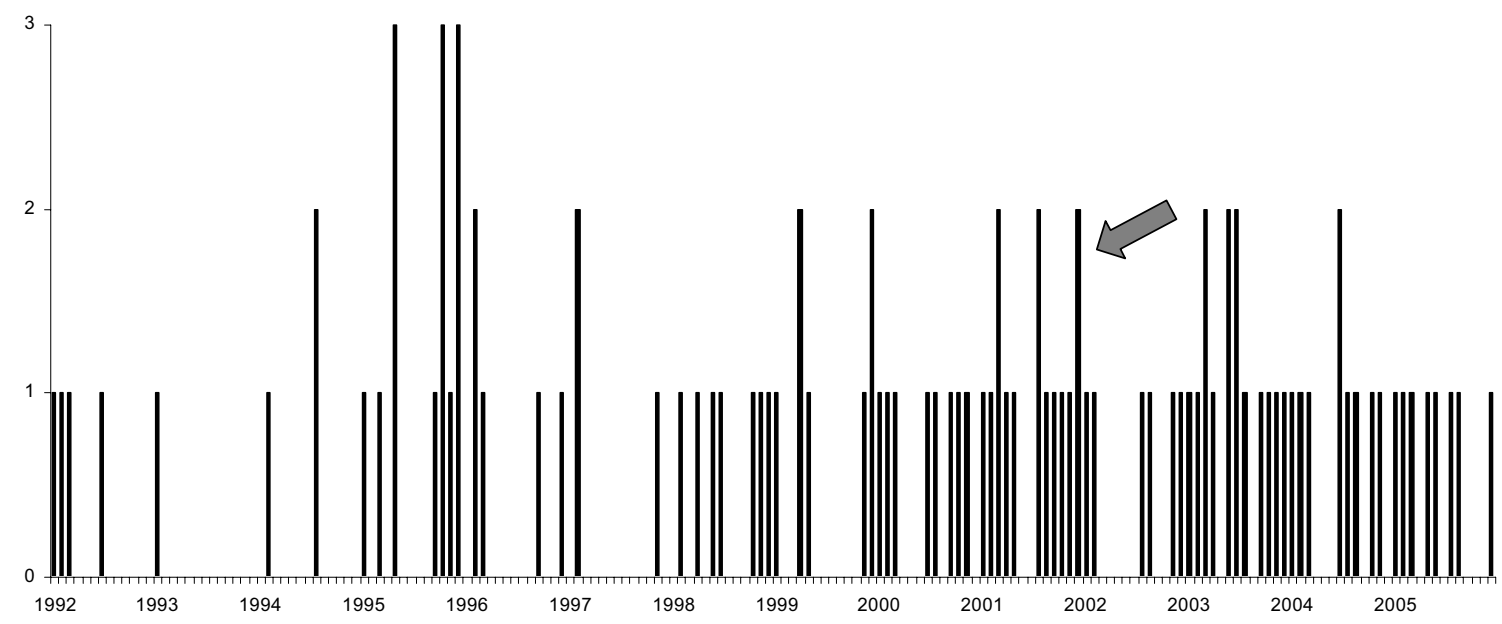

Figure 4 shows the difference between Stockholm related violence and violence not related to Stockholm teams. We note that there was no violence without Stockholm involvement during the police reallocation period.

FIGURE 4. VIOLENCE RELATED TO "ALLSVENSKAN"

WITH STOCKHOLM CLUBS MINUS WITHOUT

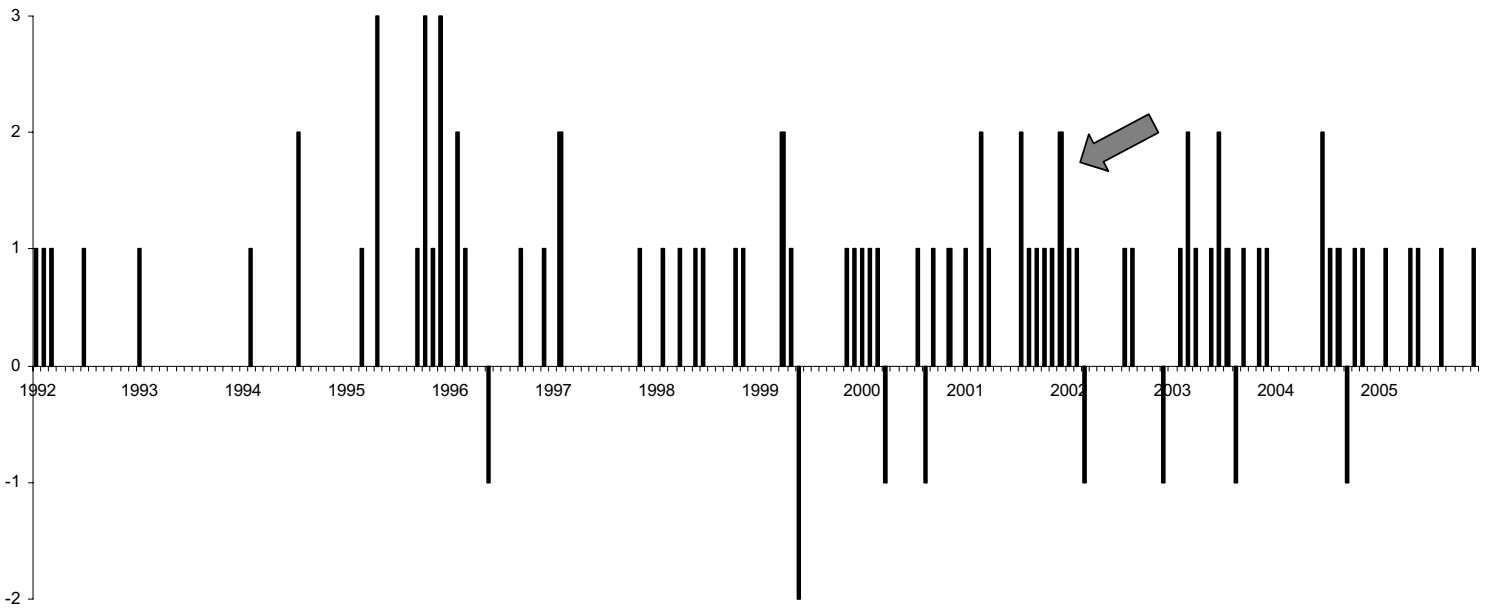


A question that arises is whether the games that have a high risk of violence are equally distributed between the periods. Because the supporter clubs of the four teams AIK, Djurgårdens IF, Hammarby IF and IFK Göteborg are several times more violent than other clubs, the fact that these teams meet relatively often within a specific period could explain much of the variation between periods. To account for this, we count the number of times any combination of these four teams meet within each 16-day period. In total, they meet between zero and three times and the average is 0.63 matches. The reallocation period we consider has one potentially violent game. As most of the other high-violence periods have more than one high-risk game, our result is strengthened when controlling for the number of high-risk games. In Figure 5, we report the difference between Stockholm-related violence and violence not related to Stockholm teams for the periods which had one high-risk game, similar to period 130 when the supporter police was reallocated. To illustrate the distribution of violence, we order these periods from the lowest to the highest participation of Stockholm clubs. Out of 64 observations, only one has more violence than the reallocation period and four periods have the same level of violence.
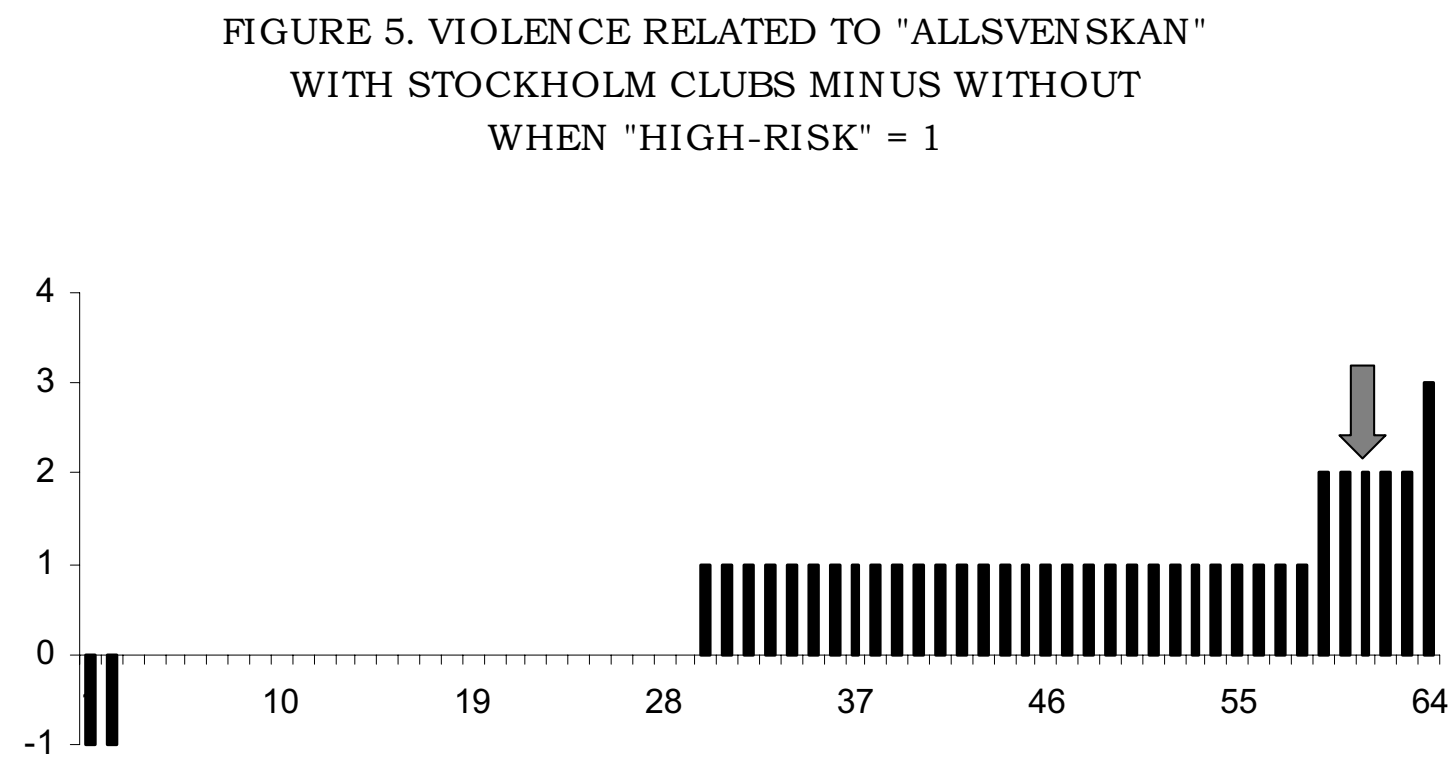


\section{The Effect of Police on Hooligan Violence}

\subsection{Empirical Strategy}

The purpose of this section is to estimate the causal effect of the police intelligence unit on supporter violence. In the first specification we use the number of violent incidents as the dependent variable. In the second specification, we use total violence according to our index as the dependent variable. We use a fixed-effects model to calculate difference-in-difference estimates. The treatment group consists of games with Stockholm involvement and the control group consists of the games without. STOCKHOLM is a dummy variable for the games with Stockholm involvement. TSUNAMI is a dummy variable for the ice hockey spring season 2005 during which the supporter police was reallocated to be responsible for the incoming goods of Tsunami victims. STOCKHOLM*TSUNAMI is our difference-in-difference interaction variable. $T$ is a vector that has components to denote three different time-period fixed effects. The error term is denoted $\varepsilon$. In other words, controlling for time and Stockholm effects, we obtain the difference in difference estimators of the effect of policing on hooligan violence using the following model:

$$
\begin{gathered}
\text { VIOLENCE }=\alpha+\beta S T O C K H O L M+\gamma T S U N A M I \\
+\delta(S T O C K H O L M * T S U N A M I)+\mu T+\varepsilon .
\end{gathered}
$$

With 28 periods and two groups (Stockholm being the treatment group and NonStockholm the control group) we obtain 56 ice hockey observations. In the soccer analysis, we have 182 16-day periods and two groups so there are 364 observations. We denote the dummy variable for the reallocation period by 9/11 ATTACK, and the difference-in-difference interaction variable STOCKHOLM*9/11 ATTACK.

We first present results following the reallocation of the supporter police due to the Tsunami and then the results following the reallocation due to the terrorist attack. 


\subsection{The Tsunami and Hooligan Violence Related to Ice Hockey}

The results from the first specification are reported in Table III. The dependent variable is the number of violent incidents. Column 1 reports the results without any timeperiod fixed effects. Our difference-in-difference estimate (STOCKHOLM*TSUNAMI) is positive and significant at the 1-percent level. The result is not affected when we add season (spring or fall) and year dummies. We note also that supporters of the Stockholm teams are significantly more violent than other teams' supporters. Table IV reports the results when the dependent variable is the index of total violence. Again, the difference-in-difference estimate is highly significant at the 1-percent level. The result is not affected by adding different time-period fixed effects. In sum, our results show that ice hockey related violence was significantly increased during the time when the supporter police for exogenous reasons was not monitoring hooligans.

In an average period there were 0.96 Stockholm-related violent incidents. The estimated effect of police reallocation, after controlling for any general effect of the Tsunami, is given by the interaction term Stockholm*Tsunami. This was 3.37. Therefore, relative to the average, Stockholm-related incidents went up by 351 percent, as a result of police reallocation. This is a large percentage increase but one must be cautious in interpreting it given the small number of observations.

\subsection{The 9/11 Terrorist Attack and Hooligan Violence Related to Soccer}

We next study the other reallocation that affected the supporter police, which took place during the soccer season. Table $\mathrm{V}$ reports the results when the dependent variable is the number of violent incidents.

The effect of reallocating supporter police has a statistically significant effect at the 5-percent level when using a difference-in-difference estimate. Adding period fixed effects and year fixed effects leaves the estimated effect arising from the differencein-difference analysis almost unaffected. Also in soccer, supporters of the Stockholm 
teams are much more violent than other supporters.

The average number of Stockholm-related violent incidents is 0.55 . The increase associated with the reallocation of the police unit caused by the terrorist attack was 1.60 incidents. Thus, the number of violent incidents increased by 291 percent. Like in the case of the Tsunami, this is a large percentage increase, but we must again be cautious because of the small number of observations.

Table VI reports the result when the index of total violence is used as the dependent variable. The results are similar. Our difference-in-difference estimate is statistically significant at the 5-percent level, also when controlling for period and year fixed effects.

\subsection{Sensitivity Analysis}

As a placebo treatment, we study difference-in-difference estimates for the periods surrounding the Tsunami period. Table VII shows which of the periods give significant results. There is no significant increase in Stockholm-related violence either before or after the Tsunami. It could be noticed that there is a Sweden-wide increase in violence during the fall of 2005 .

We also perform the placebo treatment on the periods surrounding the terrorist attack. As shown in Table VIII, there is no significant change in the number of violent incidents either before or after the period when the police was reallocated.

The expected level of violence depends on how many times the teams with the most violent supporters meet. This is determined in advance by the Swedish soccer association and is consequently exogenous. As a sensitivity analysis, we here control for the number of games when AIK, Djurgårdens IF, Hammarby IF and IFK Göteborg have played against each other. They have in total played between zero and three times against each other in the periods we consider and the average is 0.63 . The number of high-risk games in the reallocation period is one. Table IX reports the results. Because many of the other periods with a high level of violence have one, two or even three high-risk games, our results remain unaffected when controlling for high-risk games. It is also robust to adding time-period fixed effects. 


\section{Conclusion}

In this paper, we have estimated the causal effect of policing on hooligan violence, using two natural experiments that induced exogenous variation in the duties of the Stockholm Supporter Police. After the 9/11 terrorist attack in 2001 and after the Tsunami in December 2004, the supporter police was reallocated to other activities for a certain time period. We find that Stockholm-related hooligan violence significantly increased during these periods.

Our study is particularly useful because the terrorist attack and the Tsunami disaster took place outside Sweden, implying a low risk that the shocks and hooligan violence are directly correlated. In particular, in contrast to the earlier literature, we can exclude the possibility that the change in criminality is due to the criminals fearing for their own safety, rather than their reaction to the change in policing. Another novel feature is that we have data on self-reported crime by hooligans, which according to the police is of high quality and more comprehensive than police data.

As a policy implication, our analysis suggests that small police intelligence units may be effective in reducing crime. A topic for further research would be to analyze how effective such units are in reducing gang crime, and also whether there are crosscountry differences in their effectiveness. 


\section{References}

[1] Archetti, Eduardo and Romero, Amílcar (1994), "Death and Violence in Argentinian Football", in Guilianotti R, Bonney M and Hepworth M, (1994), Football, Violence and Social Identity (Routledge, NY).

[2] Corman, Hope and Mocan, H. Naci (2000), "A Time-Series Analysis of Crime, Deterrence, and Drug Abuse in New York City", American Economic Review 90: $584-604$.

[3] Di Tella, Rafael and Schargrodsky, Ernesto (2004), "Do Police Reduce Crime? Estimates Using the Allocation of Police Forces After a Terrorist Attack", American Economic Review, 94:115-33.

[4] Frosdick, Steve and Marsh, Peter (2005), Football Hooliganism, (Cullompton: Willan Publishing).

[5] Klick, Jonathan and Tabarrok, Alexander (2005), "Using Terror Alert Levels to Estimate the Effect of Police on Crime", Journal of Law and Economics, 68: 267279.

[6] Levitt, Steven (1997), "Using Electoral Cycles in Police Hiring to Estimate the Effect of Police on Crime", American Economic Review, 87: 270-90.

[7] Levitt, Steven (2002), "Using Electoral Cycles in Police Hiring to Estimate the Effect of Police on Crime: Reply", American Economic Review, 92: 1244-50.

[8] Marvell, Thomas and Moody, Carlisle (1996), "Police Levels, Crime Rates, and Specification Problems", Criminology 34: 609-46.

[9] McCrary, Justin (2002), "Using Electoral Cycles in Police Hiring to Estimate the Effect of Police on Crime: Comment", American Economic Review, 87: 1236-43. 
TABLE I. VIOLENCE RELATED TO ICE HOCKEY

\begin{tabular}{lccccc}
\hline \hline & AIK & Hammarby & Djurgården & Other & Total \\
\cline { 2 - 6 } 1992 & 0 & 0 & 1 & 1 & 2 \\
1993 & 1 & 1 & 1 & 1 & 4 \\
1994 & 1 & 0 & 0 & 1 & 2 \\
1995 & 4 & 0 & 2 & 2 & 8 \\
1996 & 2 & 0 & 2 & 0 & 4 \\
1997 & 2 & 0 & 2 & 0 & 4 \\
1998 & 0 & 0 & 1 & 1 & 2 \\
1999 & 1 & 1 & 1 & 5 & 8 \\
2000 & 0 & 1 & 1 & 0 & 2 \\
2001 & 0 & 2 & 0 & 6 & 8 \\
2002 & 0 & 0 & 0 & 0 & 0 \\
2003 & 2 & 3 & 0 & 1 & 6 \\
2004 & 0 & 1 & 1 & 0 & 2 \\
2005 & 2 & 4 & 2 & 14 & 22 \\
2006 & 1 & 1 & 0 & 2 & 4 \\
Total & 16 & 14 & 14 & 34 & 78
\end{tabular}

Notes: Each violent incident is represented by one unit of violence per supporter club involved. 1992 reports only the fall season and 2006 only the spring season. 
TABLE II. VIOLENCE RELATED TO "ALLSVENSKAN"

\begin{tabular}{lccccccc}
\hline & AIK & Djurgården & Hammarby & Göteborg & Helsingborg & Other & Total \\
\cline { 2 - 8 } 1992 & 2 & 2 & - & 1 & - & 1 & 6 \\
1993 & 1 & - & - & 1 & 0 & 0 & 2 \\
1994 & 1 & - & 2 & 2 & 0 & 1 & 6 \\
1995 & 6 & 6 & 5 & 4 & 1 & 6 & 28 \\
1996 & 2 & 3 & - & 2 & 1 & 4 & 12 \\
1997 & 3 & - & - & 2 & 0 & 1 & 6 \\
1998 & 5 & - & 3 & 4 & 2 & 2 & 16 \\
1999 & 4 & 4 & 2 & 4 & 3 & 5 & 22 \\
2000 & 5 & 0 & 5 & 6 & 2 & 6 & 24 \\
2001 & 6 & 6 & 6 & 5 & 2 & 7 & 32 \\
2002 & 2 & 3 & 3 & 5 & 2 & 5 & 20 \\
2003 & 8 & 6 & 8 & 6 & 4 & 4 & 36 \\
2004 & 3 & 4 & 6 & 4 & 5 & 6 & 28 \\
2005 & - & 2 & 7 & 5 & 3 & 5 & 22 \\
Total & 48 & 36 & 47 & 51 & 25 & 53 & 260
\end{tabular}

Notes: Each violent incident is represented by one unit of violence per supporter club involved. - are missing values due to failure of the team to stay in Allsvenskan. 
TABLE III. THE EFFECT OF POLICING ON THE NUMBER OF INCIDENTS RELATED TO ICE HOCKEY

\begin{tabular}{|c|c|c|c|}
\hline \multicolumn{4}{|c|}{ Dependent variable: NUMBER OF VIOLENT INCIDENTS } \\
\hline Sample & {$[1]$} & [2] & [3] \\
\hline \multirow[t]{2}{*}{ STOCKHOLM } & $0.630 * * *$ & $0.630 * * *$ & $0.630 * * *$ \\
\hline & $(0.236)$ & $(0.236)$ & $(0.178)$ \\
\hline \multirow[t]{2}{*}{ TSUNAMI } & -0.333 & -0.339 & $-3.394 * * *$ \\
\hline & $(0.881)$ & $(0.899)$ & $(0.829)$ \\
\hline \multirow[t]{2}{*}{ STOCKHOLM*TSUNAMI } & $3.370 * * *$ & $3.370 * * *$ & $3.370 * * *$ \\
\hline & $(1.247)$ & $(1.259)$ & $(0.943)$ \\
\hline \multirow[t]{2}{*}{ SPRING DUMMY } & No & 0.011 & 0.208 \\
\hline & & $(0.238)$ & $(0.189)$ \\
\hline YEAR FIXED EFFECTS & No & No & Yes \\
\hline \multirow[t]{2}{*}{ CONSTANT } & 0.333 & 0.328 & 0.081 \\
\hline & $(0.167)$ & $(0.204)$ & $(0.352)$ \\
\hline ADJUSTED $\mathrm{R}^{2}$ & 0.262 & 0.248 & 0.577 \\
\hline OBSERVATIONS & 56 & 56 & 56 \\
\hline
\end{tabular}

Note: Standad errors below coefficients.

*** indicates significance at the 1 percent level,

$* *$ at 5 percent and $*$ at 10 percent. 
TABLE IV. THE EFFECT OF POLICING ON TOTAL VIOLENCE RELATED TO ICE HOCKEY

\begin{tabular}{|c|c|c|c|}
\hline \multicolumn{2}{|c|}{ Dependent variable: VIOLENCE (0-3) } & \multirow[b]{2}{*}[2]{} & \multirow[b]{2}{*}{ [3] } \\
\hline Sample & {$[1]$} & & \\
\hline \multirow[t]{2}{*}{$\begin{array}{l}\text { STOCKHOLM } \\
\end{array}$} & $1.370 * * *$ & $1.370 * * *$ & $1.370 * * *$ \\
\hline & $(0.445)$ & $(0.448)$ & $(0.342)$ \\
\hline \multirow[t]{2}{*}{ TSUNAMI } & -0.444 & -0.315 & $-5.898 * * *$ \\
\hline & $(1.663)$ & $(1.691)$ & $(1.592)$ \\
\hline \multirow[t]{2}{*}{ STOCKHOLM*TSUNAMI } & $6.629 * * *$ & $6.629 * * *$ & $6.629 * * *$ \\
\hline & $(2.352)$ & $(2.368)$ & $(1.812)$ \\
\hline \multirow[t]{2}{*}{ SPRING DUMMY } & No & -0.250 & 0.083 \\
\hline & & $(0.448)$ & $(0.363)$ \\
\hline YEAR FIXED EFFECTS & No & No & Yes \\
\hline \multirow[t]{2}{*}{ CONSTANT } & 0.444 & 0.565 & 0.773 \\
\hline & $(0.314)$ & $(0.383)$ & $(0.677)$ \\
\hline ADJUSTED $\mathrm{R}^{2}$ & 0.307 & 0.308 & 0.589 \\
\hline OBSERVATIONS & 56 & 56 & 56 \\
\hline
\end{tabular}

Note: Standad errors below coefficients.

*** indicates significance at the 1 percent level,

$* *$ at 5 percent and $*$ at 10 percent. 
TABLE V. THE EFFECT OF POLICING ON THE NUMBER OF INCIDENTS RELATED TO "ALLSVENSKAN"

\begin{tabular}{|c|c|c|c|}
\hline \multicolumn{3}{|c|}{ Dependent variable: NUMBER OF VIOLENT INCIDENTS } & \multirow[b]{2}{*}{ [3] } \\
\hline Sample & {$[1]$} & [2] & \\
\hline \multirow[t]{2}{*}{ STOCKHOLM } & $0.398 * * *$ & $0.398 * * *$ & $0.398 * * *$ \\
\hline & $(0.059)$ & $(0.059)$ & $(0.055)$ \\
\hline \multirow[t]{2}{*}{ 9/11 ATTACK } & -0.155 & -0.340 & -0.602 \\
\hline & $(0.560)$ & $(0.566)$ & $(0.551)$ \\
\hline \multirow[t]{2}{*}{ STOCKHOLM*9/11 ATTACK } & $1.602 * *$ & $1.602 * *$ & $1.602 * *$ \\
\hline & $(0.792)$ & $(0.787)$ & $(0.750)$ \\
\hline PERIOD FIXED EFFECTS & No & Yes & Yes \\
\hline YEAR FIXED EFFECTS & No & No & Yes \\
\hline \multirow[t]{2}{*}{ CONSTANT } & 0.155 & 0.051 & -0.074 \\
\hline & $(0.042)$ & $(0.109)$ & $(0.144)$ \\
\hline ADJUSTED R ${ }^{2}$ & 0.125 & 0.138 & 0.217 \\
\hline OBSERVATIONS & 364 & 364 & 364 \\
\hline
\end{tabular}

Note: Standad errors below coefficients.

*** indicates significance at the 1 percent level,

$* *$ at 5 percent and $*$ at 10 percent. 
TABLE VI. THE EFFECT OF POLICING ON TOTAL VIOLENCE RELATED TO "ALLSVENSKAN"

\begin{tabular}{|c|c|c|c|}
\hline \multicolumn{4}{|c|}{ Dependent variable: VIOLENCE (0-3) } \\
\hline Sample & [1] & [2] & [3] \\
\hline \multirow[t]{2}{*}{ STOCKHOLM } & $0.812 * * *$ & $0.812 * * *$ & $0.812 * * *$ \\
\hline & $(0.115)$ & $(0.114)$ & $(0.110)$ \\
\hline \multirow[t]{2}{*}{ 9/11 ATTACK } & -0.204 & -0.440 & -1.058 \\
\hline & $(1.099)$ & $(1.110)$ & $(1.094)$ \\
\hline \multirow[t]{2}{*}{ STOCKHOLM*9/11 ATTACK } & $3.188 * *$ & $3.188 * *$ & $3.188 * *$ \\
\hline & $(1.554)$ & $(1.543)$ & $(1.489)$ \\
\hline PERIOD FIXED EFFECTS & No & Yes & Yes \\
\hline YEAR FIXED EFFECTS & No & No & Yes \\
\hline \multirow[t]{2}{*}{ CONSTANT } & 0.204 & -0.049 & -0.318 \\
\hline & $(0.081)$ & $(0.213)$ & $(0.286)$ \\
\hline ADJUSTED R ${ }^{2}$ & 0.135 & 0.147 & 0.206 \\
\hline OBSERVATIONS & 364 & 364 & 364 \\
\hline
\end{tabular}

Note: Standad errors below coefficients.

*** indicates significance at the 1 percent level, $* *$ at 5 percent and $*$ at 10 percent. 
TABLE VII. PLACEBO TREATMENT ON

THE PERIODS SURROUNDING THE TSUNAMI

\begin{tabular}{|c|c|}
\hline \multicolumn{2}{|c|}{ Dependent variable: NUMBER OF VIOLENT INCIDENTS } \\
\hline Sample & {$[1]$} \\
\hline \multirow[t]{2}{*}{ STOCKHOLM*PERIOD 24} & 0.261 \\
\hline & $(0.953)$ \\
\hline \multirow[t]{2}{*}{ STOCKHOLM*PERIOD 25} & -0.739 \\
\hline & $(0.953)$ \\
\hline \multirow[t]{2}{*}{ STOCKHOLM*TSUNAMI 26} & $3.261 * * *$ \\
\hline & $(0.953)$ \\
\hline \multirow[t]{2}{*}{ STOCKHOLM*PERIOD 27} & 0.261 \\
\hline & $(0.953)$ \\
\hline \multirow[t]{2}{*}{ STOCKHOLM*PERIOD 28} & -0.739 \\
\hline & $(0.953)$ \\
\hline \multirow[t]{2}{*}{ STOCKHOLM } & $0.739 * * *$ \\
\hline & $(0.194)$ \\
\hline \multirow[t]{2}{*}{ PERIOD 24} & -0.174 \\
\hline & $(0.674)$ \\
\hline \multirow[t]{2}{*}{ PERIOD 25} & -0.174 \\
\hline & $(0.674)$ \\
\hline \multirow[t]{2}{*}{ TSUNAMI 26} & -0.174 \\
\hline & $(0.674)$ \\
\hline \multirow[t]{2}{*}{ PERIOD 27} & $3.826 * * *$ \\
\hline & $(0.674)$ \\
\hline \multirow[t]{2}{*}{ PERIOD 28} & -0.739 \\
\hline & $(0.674)$ \\
\hline \multirow[t]{2}{*}{ CONSTANT } & 0.174 \\
\hline & $(0.137)$ \\
\hline ADJUSTED $\mathrm{R}^{2}$ & 0.572 \\
\hline OBSERVATIONS & 56 \\
\hline
\end{tabular}

Note: Standad errors below coefficients.

*** indicates significance at the 1 percent level,

** at 5 percent and $*$ at 10 percent. 
TABLE VIII. PLACEBO TREATMENT ON

THE PERIODS SURROUNDING THE 9/11 ATTACK

\begin{tabular}{|c|c|}
\hline \multicolumn{2}{|c|}{ Dependent variable: NUMBER OF VIOLENT INCIDENTS } \\
\hline Sample & [1] \\
\hline \multirow[t]{2}{*}{ STOCKHOLM*PERIOD 128} & 0.616 \\
\hline & $(0.798)$ \\
\hline \multirow[t]{2}{*}{ STOCKHOLM*PERIOD 129} & 0.616 \\
\hline & $(0.798)$ \\
\hline \multirow[t]{2}{*}{ STOCKHOLM*9/11 ATTACK 130} & $1.616 * *$ \\
\hline & $(0.798)$ \\
\hline \multirow[t]{2}{*}{ STOCKHOLM*PERIOD 131} & 0.616 \\
\hline & $(0.798)$ \\
\hline \multirow[t]{2}{*}{ STOCKHOLM*PERIOD 132} & 0.616 \\
\hline & $(0.798)$ \\
\hline \multirow[t]{2}{*}{ STOCKHOLM } & $0.384 * * *$ \\
\hline & $(0.060)$ \\
\hline \multirow[t]{2}{*}{ PERIOD 128} & -1.158 \\
\hline & $(0.564)$ \\
\hline \multirow[t]{2}{*}{ PERIOD 129} & -1.158 \\
\hline & $(0.564)$ \\
\hline \multirow[t]{2}{*}{ 9/11 ATTACK 130} & -1.158 \\
\hline & $(0.564)$ \\
\hline \multirow[t]{2}{*}{ PERIOD 131} & -1.158 \\
\hline & $(0.564)$ \\
\hline \multirow[t]{2}{*}{ PERIOD 132} & -1.158 \\
\hline & $(0.564)$ \\
\hline \multirow[t]{2}{*}{ CONSTANT } & 0.158 \\
\hline & $(0.042)$ \\
\hline ADJUSTED R ${ }^{2}$ & 0.113 \\
\hline OBSERVATIONS & 364 \\
\hline
\end{tabular}

Note: Standad errors below coefficients.

*** indicates significance at the 1 percent level,

** at 5 percent and $*$ at 10 percent. 
TABLE IX. POLICING, VIOLENCE AND HIGH-RISK GAMES

\begin{tabular}{lc}
\hline \hline Dependent variable: NUMBER OF VIOLENT INCIDENTS \\
\hline Sample & {$[1]$} \\
\hline STOCKHOLM & $\mathbf{0 . 3 9 8 * * *}$ \\
& $(0.056)$ \\
9/11 ATTACK & -0.242 \\
& $(0.534)$ \\
STOCKHOLM ${ }^{*}$ ATTACK & $\mathbf{1 . 6 0 2 * *}$ \\
& $(0.755)$ \\
HIGH-RISK GAMES & $\mathbf{0 . 2 3 4 * * *}$ \\
& $(0.038)$ \\
CONSTANT & 0.009 \\
& $(0.046)$ \\
ADJUSTED R & \\
OBSERVATIONS & 0.207 \\
\hline
\end{tabular}

Note: Standad errors below coefficients.

*** indicates significance at the 1 percent level,

** at 5 percent and $*$ at 10 percent. 